\title{
Optimization of fermentation condition for cellulase enzyme production from Bacillus sp.
}

\author{
Maidul Islam, Palash Kumar Sarkar²*, Dr. A.K.M. Mohiuddin³, Md. Suzauddula4 \\ ${ }^{1}$ Department of Biotechnology and Genetic Engineering, Mawlana Bhashani Science and Technology University. \\ ${ }^{2}$ Sr. Scientific Officer, Microbial Biotechnology Division, National Institute of Biotechnology, Ganakbari, Savar, Dhaka-1349, Bangladesh. \\ ${ }^{3}$ Biotechnology and Genetic Engineering Department, Mawlana Bhashani Science and Technology University (MBSTU), Santosh, Tangail-1902. Bangladesh. \\ ${ }^{4}$ Department of Nutrition and Food Engineering, Daffodil International University, Dhaka-1207, Bangladesh. \\ *Corresponding Author email: palashnib@yahoo.com, maidulmbstu@gmail.com, akmmohiu@yahoo.com, suzauddula34-506@diu.edu.bd
}

\section{Doi: 10.2478/mjhr-2019-0009}

\section{Abstract:}

Cellulase is an important enzyme in present-day of industrial biotechnology. The current study is concerned with the production and partial characterization of cellulase enzyme from Bacillus sp. The effect of various fermentation conditions for cellulase production through shake-flask culture was investigated. Maximum enzyme production was obtained after 24 hours of incubation in fermentation medium with pH 3.5 at $35^{\circ} \mathrm{C}$ under having agitation at $150 \mathrm{rpm}$ while inoculums volume 1\% was applied. Enzyme production was 1.91 times higher after optimizing the production condition as compared to the basal media. Cellulase characterization revealed that optimum activity was at pH 5.5 and $50{ }^{\circ} \mathrm{C}$ for 50 minutes. About $68 \%$ of the activity retained after heating the crude enzyme solution at $50^{\circ} \mathrm{C}$ for 30 minutes. This nature makes cellulase a suitable candidate for current mainstream biomass conversions for sustainable agriculture and industrial processes.

Keywords: Production of cellulase enzyme, Cellulase enzyme from Bacillus sp, Fermentation condition of enzyme production, Acidic cellulase.

\subsection{Introduction:}

All living system regulates its biological activity through enzymes. An enzyme is a protein molecule that is biological catalyst influences the rate of a reaction, most cellular reactions occurs about a million times faster than they would in the absence of an enzyme. The purpose of an enzyme in a cell is to allow the cell to carry out biochemical reactions very quickly. Outstanding features of enzymes in comparison to chemical catalysts are substrate specificity and specificity in promoting of only one biochemical reaction with their substrate ensuring synthesis of a specific bio-molecular product without the concomitant production of byproducts [1]. At least 2,000 different enzymes are now known, each of them capable of catalyzing a specific reaction. With the understanding of the nature of enzymes and their catalytic potential, the use of enzymes has gradually been extended in variety of fields such as food production, brewing, pharmaceuticals, medicine, textiles and detergents [2].

Cellulase enzymes have been produced by a plethora of microorganisms including bacteria and fungi. Different studies have been investigated for the biosynthesis of a highly active preparation in high amount [3]. Many researchers cultivated a lot of microorganisms to have cellulases of desired quality under liquid and solid state fermentation conditions for the low cost production of enzyme using agricultural organic waste[4].The significance of thermophilic cellulase enzymes in a wide range of industries including bio-ethanol and value-added organic compounds production from renewable agricultural residues[5]. Enzyme production from micro-organisms and to ameliorate its productivity, a variety of factors such as inoculum size, pH value, temperature, presence of inducers, medium additives, aeration and growth time needs to be optimized [6]. The specific objectives of the present research work is to test the ability of the isolate to produce cellulase enzyme, laboratory scale production of cellulase enzyme from identified bacterial isolate, optimization of cultural (environmental) conditions for the production of cellulase enzyme, partial characterization of crude cellulase enzyme.

\subsection{Materials and methods}

The present study was performed in the Microbial Biotechnology Division of National Institute of Biotechnology (NIB), Ganakbari, Savar, Dhaka, Bangladesh.

\subsection{Organism and culture maintenance}

The bacterial culture of Bacillus sp. was taken from the available culture-bank of NIB. It was revived on nutrient agar media. The culture was incubated at $37^{\circ} \mathrm{C}$ and stored at $4^{\circ} \mathrm{C}$ in refrigerator (SUPERARISTON XL5-280CW) for routine laboratory use only and it was preserved in $40 \%$ glycerol broth at $-20^{\circ} \mathrm{C}$ for long term storage.

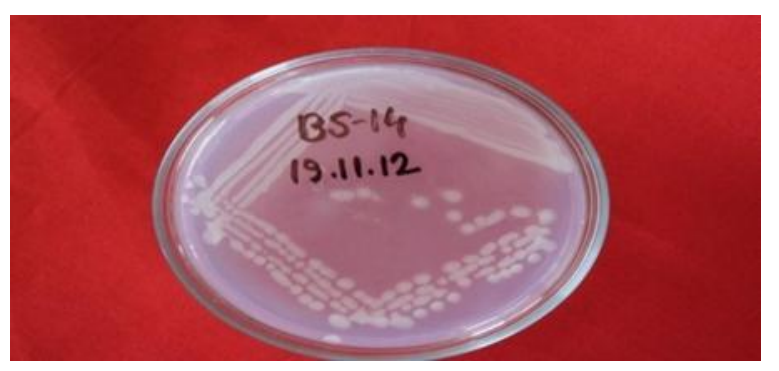

Figure 1: Pure culture of Bacillus sp.

2.2. Production Of Crude Cellulase From Bacillus Sp.
Preparation of inoculum: The fresh inoculum was prepared with nutrient broth medium. Then fifty milliliters of broth was prepared in a $150 \stackrel{1}{\mathrm{ml}}$ conical flask, sterilized, cooled and a loop full of a freshly bacterial colony was aseptically inoculated and incubated at $37^{\circ} \mathrm{C}$ with 150 rpm in a rotary shaking incubator. Standard curve of glucose was prepared by DNS method and following its procedure.

Assessment of cellulose activity through shaking culture fermentation: The enzyme production was carried out in the modified Czapek's basal sterilized medium. The modified media composition is $0.1 \% \mathrm{~K} 2 \mathrm{HPO} 4,0.05 \% \mathrm{MgSO} .7 \mathrm{H} 2 \mathrm{O}, 0.3 \% \mathrm{KNO}, 0.001 \% \mathrm{FeSO} .5 \mathrm{H} 2 \mathrm{O}, 0.15 \%\left(\mathrm{NH}_{4}\right) \mathrm{SO}_{\mathrm{S}}, 0.12 \% \mathrm{Yeast} \mathrm{extract,}^{2}$ $1 \%$ carboxy methyl cellulose (CMC). The initial pH of the medium was adjusted to 7.0. Erlenmeyer flasks ( $250 \mathrm{ml}$ ) containing $100 \mathrm{ml}$ of medium were inoculated with $1.0 \mathrm{ml}$ of an overnight culture $\left(0 . \mathrm{D}_{600}=1.084\right)$ and incubated at $37^{\circ} \mathrm{C}$ in a rotary shaker incubator at $150 \mathrm{rpm}$ for $48 \mathrm{hrs}$.

Separation of cells from culture media: After the incubation, the fermented broth was centrifuged in a refrigerated centrifuge machine at 8000 rpm for 15 minutes at $4^{\circ} \mathrm{C}$. The cell-free culture supernatant was taken by micropipette and used for enzyme assay.

Cellulase activity assay: $1 \%(\mathrm{w} / \mathrm{v}$ ) Carboxymethyl cellulose was used as substrate in $0.05 \mathrm{M}$ sodium citrate buffer (pH 4.8 ) for determination of cellulase activity [7]. The mixture solution contained $80 \mathrm{ml}$ substrates solution and $0.2 \mathrm{ml}$ suitably diluted enzyme and incubated for 10 minutes at $50^{\circ} \mathrm{C}$. Then the enzyme and substrate reaction was stopped by adding $3.0 \mathrm{ml}$ of di-nitrosalicylic acid (DNS). The reducing sugar released was quantified by the Miller reaction [8]. The absorbance was measured at $540 \mathrm{~nm}$ with a spectrophotometer (Jenway 6305, USA). 
Enzyme activity $(\mathrm{U} / \mathrm{ml})=\frac{\mu \text { g glucose } \times \mathrm{DF}}{180.156 \times \text { Incubation time }} \times \frac{\text { Total volume of reaction mixture }}{\text { Enzyme used }}$

\subsection{Results and Discussion}

The bacterial culture Bacillus sp. was maintained on nutrient agar medium and stored at $4^{\circ} \mathrm{C}$ in a refrigerator. Subcultures were performed at 15 days regular interval. Microscopic observation and grams staining showed that bacteria were rod-shaped, purple-colored, and belongs to the Bacillus genus.

\subsection{Optimization of cellulase production}

Effects of temperature on enzyme production: For the determination of the optimum temperature of enzyme production, the fermentation was carried out at different temperatures $\left(32^{\circ} \mathrm{C}, 35^{\circ} \mathrm{C}, 37^{\circ} \mathrm{C}, 40^{\circ} \mathrm{C}\right.$, and $\left.42^{\circ} \mathrm{C}\right)$. Figure- 1 illustrates the correlation between enzyme production and temperature. Bacterial isolate was found to grow and produce cellulase at all tested different temperatures but the maximum enzyme production was achieved at $35^{\circ} \mathrm{C}$. A reduction of enzyme production was observed at a temperature above $40^{\circ} \mathrm{C}$.

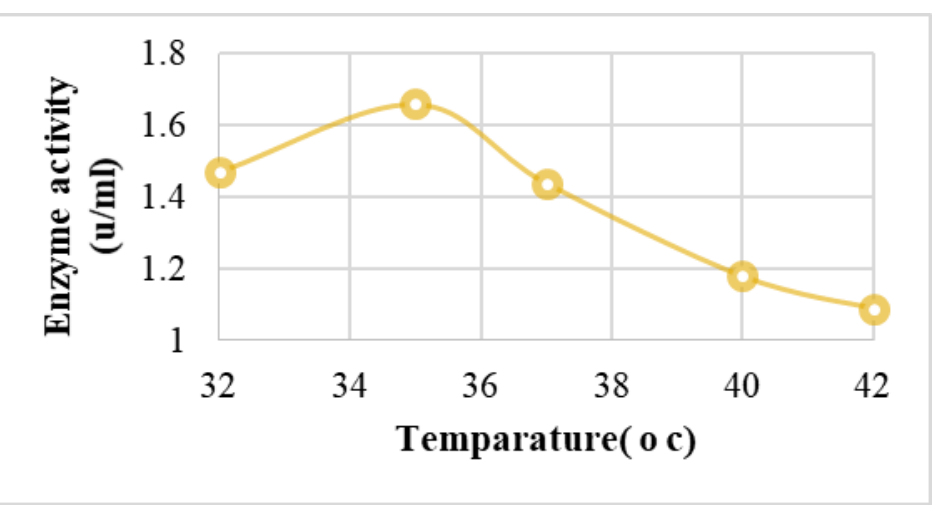

Figure 1: Effect temperature on cellulase production by of Bacillus sp.

Effect of $\mathrm{pH}$ on enzyme production: The initial $\mathrm{pH}$ of the medium markedly affects the growth of microbes and enzyme production as well. To determine the optimum $\mathrm{pH}$ for enzyme production, the cultivation was carried out in the medium at different initial $\mathrm{pH}$ values. The result in fig.02 shows that there was a stimulation of enzyme synthesis with a pH of 3.0 to 3.5 and higher enzyme synthesis was found at pH 3.5. Besides at pH 3.0 the growth was lower.

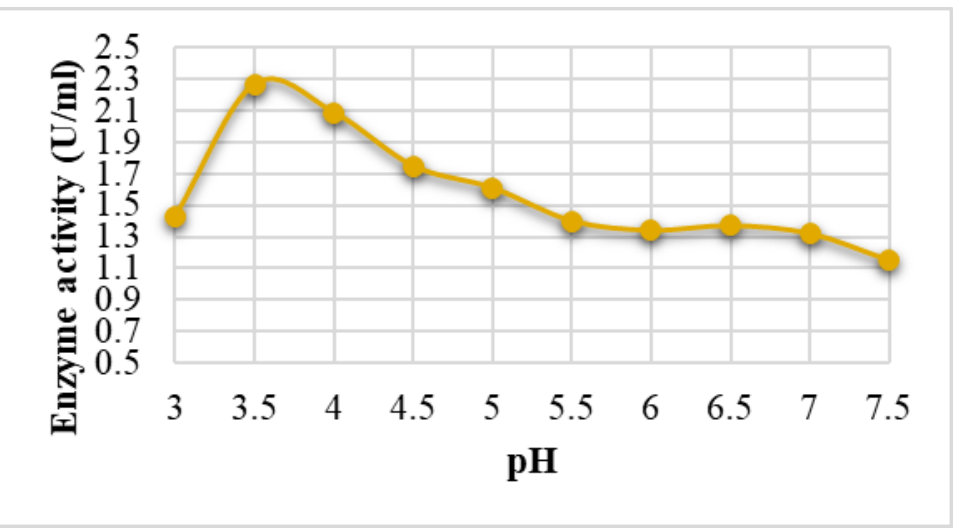

Figure 2: Effects of $\mathrm{pH}$ on cellulase production by Bacillus sp.

Effect of incubation period on enzyme production: Figure-03 illustrates the correlation among incubation period and enzyme activity. It was observed that, the level of cellulase increased linearly from 24 to $48 \mathrm{~h}$ and thereafter decreased more rapidly as the fermentation approached its end point. Thus, the maximum enzyme activity was found at $24 \mathrm{hrs}$ of cultivation.

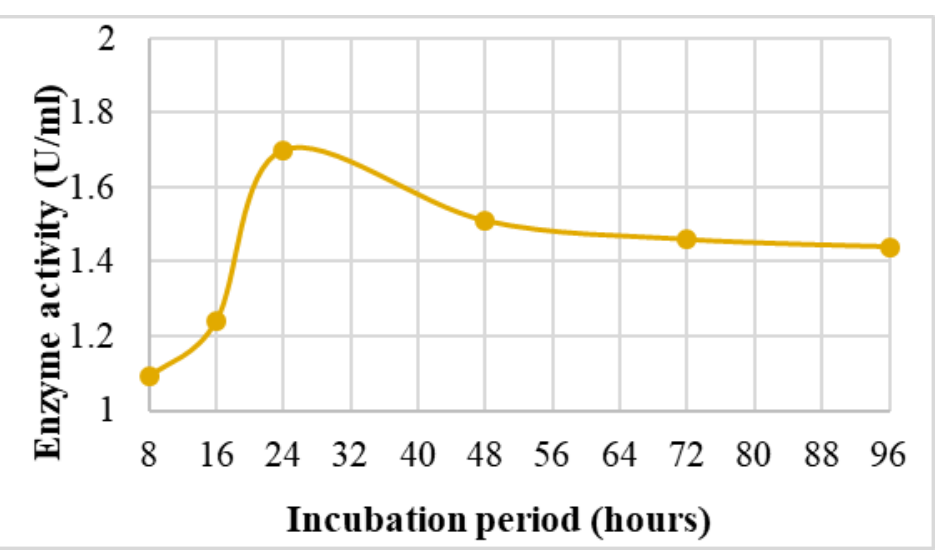

Figure 3: Effect of incubation period on cellulase production by Bacillus sp.

Effect of different inoculum volume on cellulase production: The different levels of inoculum were tested for the production of cellulase. The production of enzyme was increased at $1 \%$ inoculum level. As the inoculum level was further increased, the production of the enzyme was gradually inhibited. 


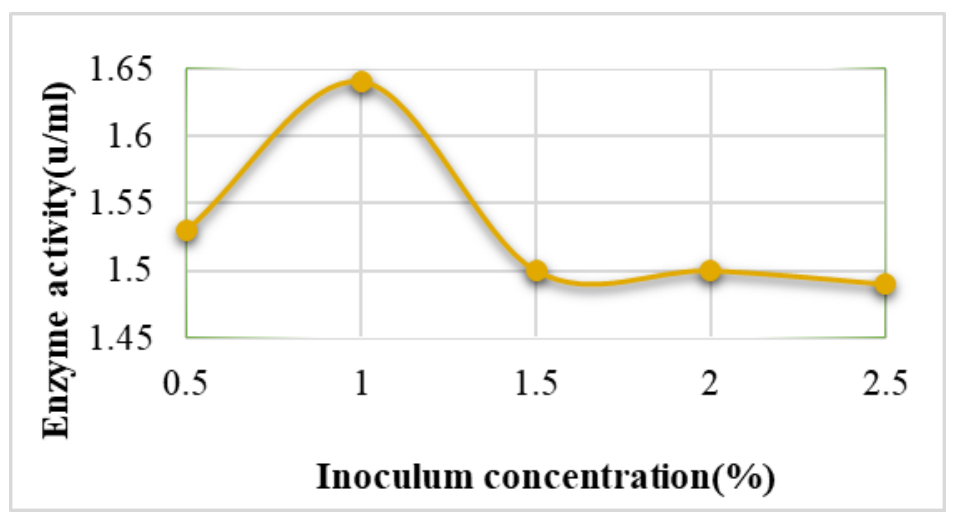

Figure 4: Effect of inoculum concentration on cellulase production by Bacillus sp.

Effect of optimized production parameters on enzyme production: The production of cellulase enzyme was again carried out using optimum production parameters at the same procedure described above. Figure 5 shows the effect of optimized production parameters on cellulase production. Before optimization and after optimization above All increase ratio shown 100:191 percentages.

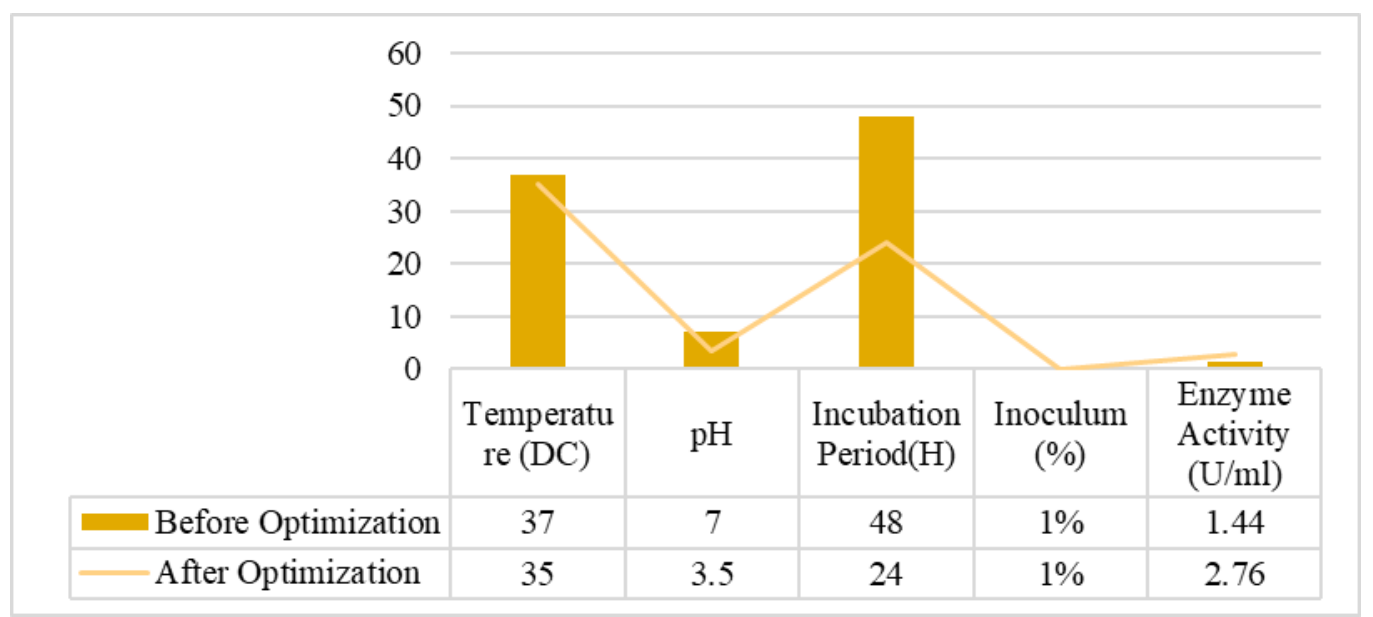

Figure 5: Effect of the optimized production parameters on cellulase production

\subsection{Characterization Of Crude Cellulase}

Effect of temperature on enzyme activity: The supernatant cellulytic activities were assayed at different temperatures ranging from $30-80^{\circ} \mathrm{C}$ for $30 \mathrm{~min}$. Enzyme activity increased with temperature within the range of $40-60^{\circ} \mathrm{C}$. A reduction in enzyme activity was observed at temperatures above $60^{\circ} \mathrm{C}$. It may conclude that the enzyme has a broad temperature range for showing its catalytic activity. Figure 06 shows the relation between enzyme activity and assay temperatures.

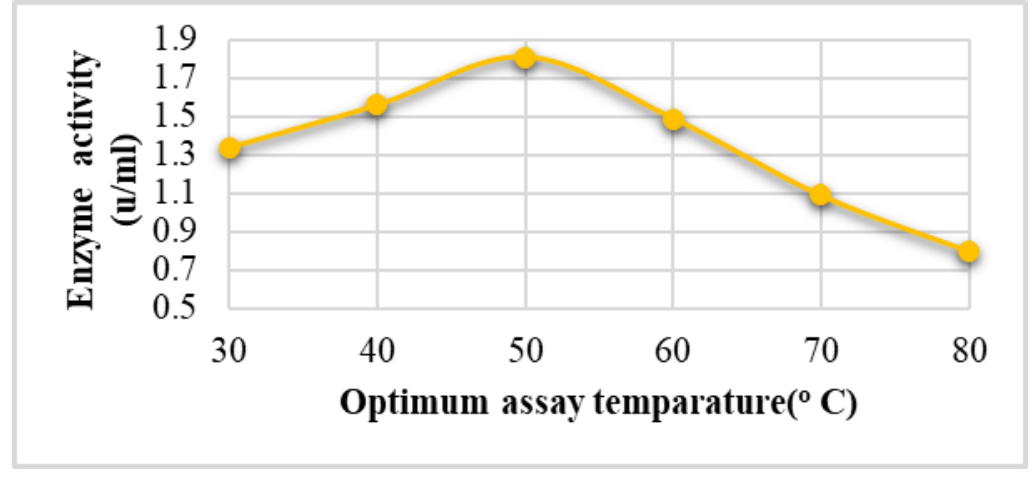

Figure 6: Effect of temperature on enzyme activity.

Effect of $\mathrm{pH}$ on cellulase activity: The effect of varied $\mathrm{pH}$ (4.0-7.5) on enzyme assay was studied. It can be seen from figure 07 that the enzyme activity started increasing from $\mathrm{pH} 4.5$ and the maximum activity was found at $\mathrm{pH}$ 5.0. 


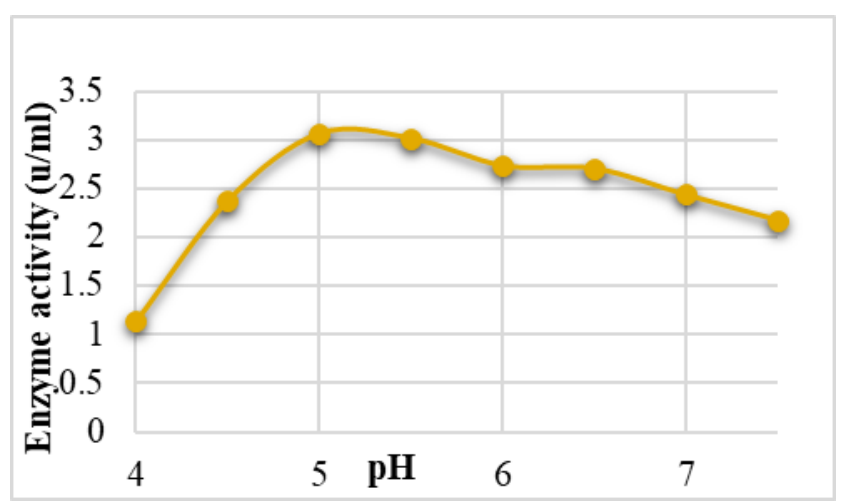

Figure 7: Effect of pH on enzyme activity.

Determination of optimum reaction time for enzyme action: All enzymes have an optimum incubation time for showing its maximum catalytic activity. For determination of optimum incubation period, enzyme assay was carried out at different incubation period at constant temperature and pH. It was found that the enzyme exhibited its maximum activity at 50 min of incubation. Results are shown in Figure 08.

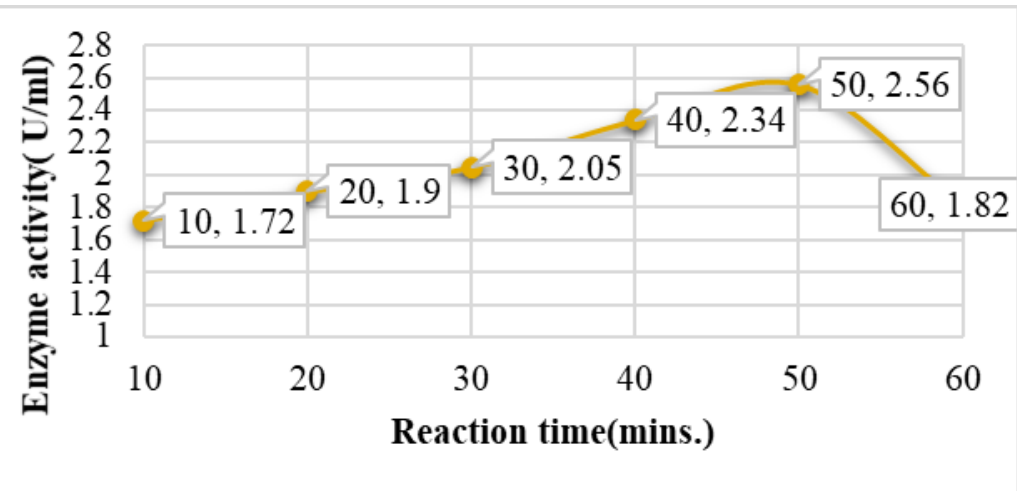

Figure 8: Effect of reaction time on enzyme activity.

Thermo stability of crude cellulase: Temperature stability of the cellulase enzyme of the Bacillus sp. is shown in fig 9. It was found that, about $68 \%$ of the activity was retained after heating the crude enzyme solution at $50^{\circ} \mathrm{C}$ for $30 \mathrm{~min}$ but the enzyme stability was partially declined when heated at $80^{\circ} \mathrm{C}$. From the experiment, it was concluded that the enzyme was moderately thermo stable.

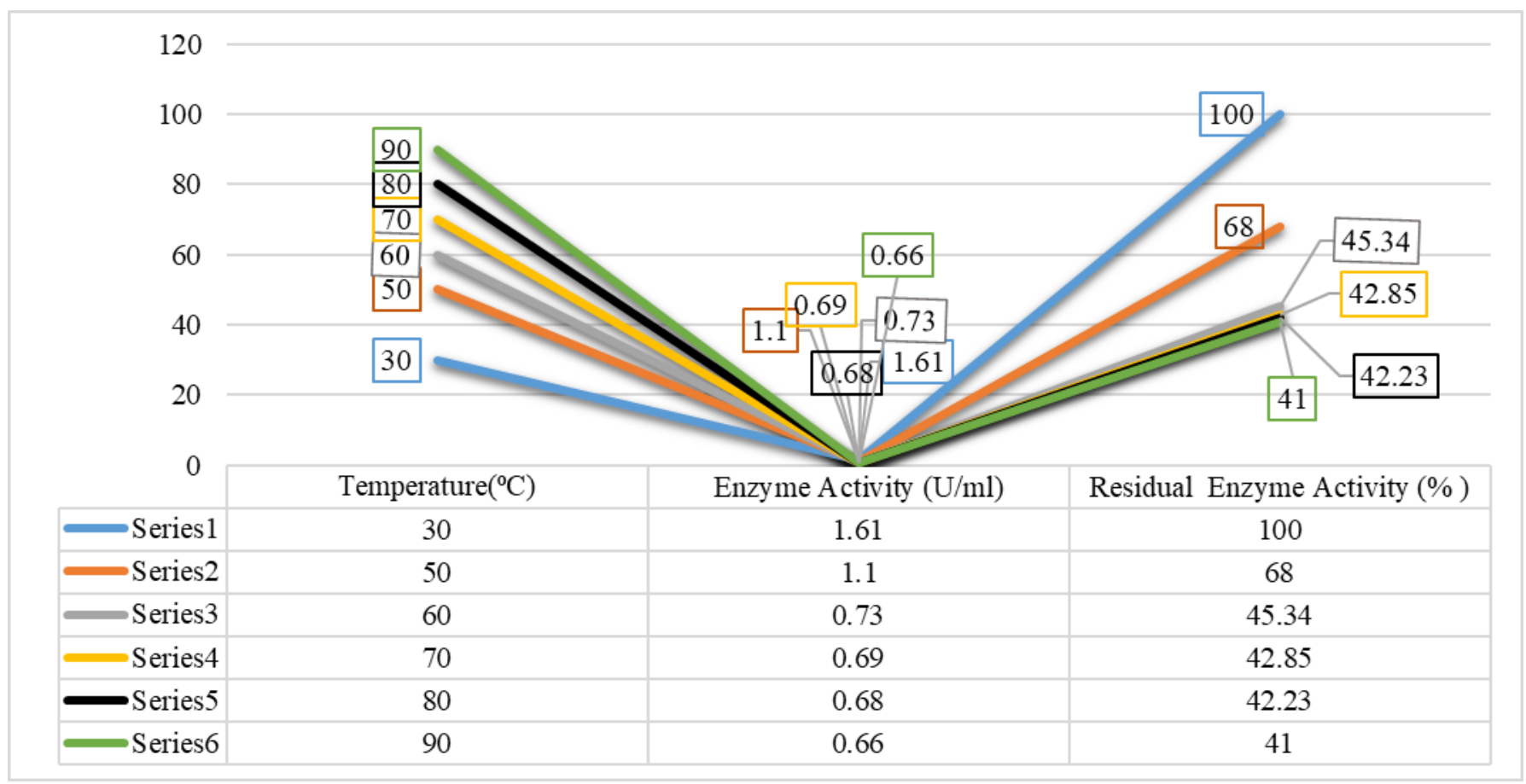

room temperature is not suitable for the storage of this enzyme. Cellulase retained only $68 \%$ of the activity after storing at room temperature for 28 days. The activity $(1.60 \mathrm{U} / \mathrm{ml}))$ measured before storage was expressed as $100 \%$.

\begin{tabular}{|l|l|l|l|l|l|}
\hline Days & 0 day & 7 days & 14 days & 21 days & 28 days \\
\hline Activity (u/ml) & 1.6 & 1.52 & 1.45 & 1.23 & 1.10 \\
\hline Storage Stability & $100 \%$ & $95 \%$ & $90 \%$ & $76 \%$ & $68 \%$ \\
\hline
\end{tabular}

Storage stability of cellulase. 
Cellulases are hydrolytic enzymes which are synthesized by several microorganisms during their growth on cellulosic materials. Currently, most of the industrial and laboratory cellulases are obtained from fungi due to their high enzyme activity, but several factors suggest that bacteria may have greater potential [9]. Bacteria often have a higher growth rate than fungi allowing for higher rate of enzyme production. Most importantly, they show a tendency to be more heat stable and are easier for genetic work. Several bacterial genera reported for cellulolytic activities include Bacillus, Clostridium, Cellulomonas Rumminococcus, Alteromonas, Acetivibrio etc. Among bacteria, Bacillus species are well known for production of CMCase under a liquid culture medium $[10,11]$. However, several reports are available on characterization of alkalophilic CMCase, but information on acidophilic CMCase is still scarce. Present study deals with the production condition (environmental) optimization and characterization of the acido thermophilic CMCase produced by Bacillus sp. for the exploitation of abundant biomass cellulosic.

A number of microorganisms hydrolyzing CMC were provided and performed Carboxymethyl-cellulase (CMCase) activity test for detect their cellulolytic potential. Of them, referred isolate was selected for further studies based on the highest activity in liquid fermentation medium .The strain was found to be gram positive, rod shaped, and aerobic in nature In previous studies, diverse types of genera have been reported for producing the cellulose enzyme including B. subtilis , Marinobacter, Penicillium [12,13,14]. Optimization of culture conditions is very important for maximum microbial growth and enzyme production by microorganisms [15]. Among the physical and chemical parameters, optimum temperature, $\mathrm{pH}$ range, carbon and nitrogen sources are the most important for microbial enzyme production.

The effect of $\mathrm{pH}$ on the cellulase production was examined at various $\mathrm{pH}$ values ranging from $\mathrm{pH} 3.0$ to 7.5. In this study we got the maximum production of cellulase at pH 3.5. It is reported that Irfan et al. found maximum cellulase produced from Bacillus subtilis K-18 at pH 5.0 [16]. Activity profile of enzyme showed its highest activity at $\mathrm{pH} 5.0$ and more than $70 \%$ of the activity still retained even the $\mathrm{pH}$ dropped to 4.5 . These results represent the acidophilic nature of enzyme. On increasing the pH level from 4.0 to 7.5 , the enzyme activity was reduced progressively. Several studies have been conducted on alkaline stable cellulases from Bacillus sp. [17, 18]. However, there are only a few reports on thermo acid stable cellulases from Bacillus species [19]. Some previous workers have also reported that the cellulase enzymes produced by several Bacillus sp. are stable over a wide $\mathrm{pH}$ range [20,21].

Temperature is a vital environmental factor which controls the growth and production of metabolites by microorganisms and this is usually varied from one organism to another [22]. In this study, different incubation temperatures were evaluated for fermentation conditions. Maximum enzyme production was observed at $35^{\circ} \mathrm{C}$. Biosynthesis of cellulase was significantly decreased with the increase in the incubation temperature beyond $40^{\circ} \mathrm{C}$. The optimum temperatures for cellulase production by Bacillus spp. are quite variable. The optimum temperature range from 300C for Bacillus alcalophilus S34 [23] 400C for Bacillus subtilis, Bacillus circulans and other Bacillus isolates [24] and 45oC for Bacillus amyloliquefaciens [6]. When the temperature was increased up to $43^{\circ} \mathrm{C}$, the enzyme activity markedly declined.

During shake culture study, it was found that the rate of enzyme concentration was ameliorated with the increase in the fermentation period and had its maximum activity after 24 hour incubation. An incubation time more than 48 hours did not increase the enzyme production. The kinetics of enzyme synthesis is related to growth of the microorganism. Cellulase activities in the broth during fermentation for cellulase production in 2L STR. Overall, maximum cellulase activity was obtained after 24-hour of fermentation having recorded activities $0.079 \mathrm{U} / \mathrm{ml}$ CMCase [25]. The growth profile of the bacterium during fermentation seen that the cellulase was being produced during growth phase of the B. pumilus EB3. This is in agreement with the previous study which showed that cellulase is a growth-associated product.

Inoculum volume plays a vital role in the microbial fermentation[26]. In our study, we found that $1 \%$ inoculum induced the maximum cellulase production As the inoculum level increased, the production of enzyme was gradually decreased. It may be due to the fact that at high inoculum concentration in media causes nutrient insufficiency, and leads to lower growth of bacteria. That resulted in the accumulation of other by products in the fermentation medium and the production of the enzyme was also inhibited. Thus, the production of cellulase was affected at higher concentration of inoculum. Different parameters optimization and media manipulation are one of the most important techniques for optimum enzyme production in industrial level. In our study, enzyme production was 1.91 times higher after optimizing the production condition as compared to the basal media.

The activity depends on temperature, exhibiting an optimum temperature above which the activity decreases. The maximum activity $(1.81 \mathrm{U} / \mathrm{ml}) \mathrm{was}$ displayed at $50^{\circ} \mathrm{C}$. Further increase in temperature resulted in decrease in the activity of cellulase. Reported that enzyme obtained from Bacillus sp. AB68 was active in a broad temperature range between 20 and $90^{\circ} \mathrm{C}$, with an optimum of $50^{\circ} \mathrm{C}$. In case of thermostabilty, the enzyme retained $68 \%$ activity after heating at $50^{\circ} \mathrm{C}$ for $30 \mathrm{~min}$. After this time the activity decreased drastically[27]. Thus, this enzyme is moderately thermo stable. Enzyme stability bears a great importance for the economical industrial application. Hence it is a considerable means to stabilize the enzyme under storage conditions. Temperature is an important factor for storage of enzymes. In our study, enzyme was stored at room temperature for 28 days. But, the room temperature was not suitable for the storage of enzyme, thus causing the reduction of enzyme activity. Only $68 \%$ of the activity retained at room temperature after 28 days. Cellulase solids and concentrated liquid solutions are strong enough to permit long term storage in the freezer and refrigerator respectively.

\subsection{Conclusion}

The results of our study suggest that the cellulase secreted by Bacillus sp. is acidophilic in nature. Enzymes that are active in acidic pH ranges are usually desirable for biomass conversion of lignocelluloses waste. Acidic cellulases can also be useful for industrial application such as animal feed industry, clarification of fruit juices, and other biotehnol industry. In future acidic cellulase producing bacteria might have a promising use in agricultural field for cellulosic waste degradation.

\subsection{Conflict of Interest}

There is no conflict of interest

\subsection{Acknowledgements}

The authors thank the Department of Biotechnology and Genetic Engineering and the Library of Mawlana Bhashani Science and Technology University for all kind of academic supports. Authors also acknowledge Head, Department of Biotechnology and Genetic Engineering, Mawlana Bhashani Science and Technology University for his help and support.

\section{References}

[1] F.B. Armstrong, “Biochemistry”, 2nd Ed. Oxford University press, New York-Oxford, 1983.

[2] P. Brodelius, E.J. Vandamme, H.J. Rehm, and G. Reed, “Em Biotechnology volume 7a”, Enzyme Technology, 1987.

[3] P. Nigam, and K.A. Prabhu, "Effect of cultural factors on cellulase biosynthesis in submerged bagasse fermentation by basidiomycetes cultures", Journal of basic microbiology, Vol. 31(4), 285-292, 1991. doi:10.1002/jobm.3620310411

[4] A. Pandey, P. Selvakumar, C.R. Soccol, and P. Nigam, "Solid state fermentation for the production of industrial enzymes", Current science, 149-162, 1999.

[5] E. Hardiman, M. Gibbs, R. Reeves, and P. Bergquist, "Directed evolution of a thermophilic $\beta$-glucosidase for cellulosic bioethanol production", Applied biochemistry and biotechnology, Vol. 161(1-8), 301-312, 2010. doi:10.1007/s12010-009-8794-6

[6] G. Immanuel, R. Dhanusha, P. Prema, and A. Palavesam, "Effect of different growth parameters on endoglucanase enzyme activity by bacteria isolated from coir retting effluents of estuarine environment", International Journal of Environmental Science \& Technology, Vol. 3(1), 25-34, 2006. doi:10.1007/bf03325904 
[7] T.K. Ghose, “Measurement of cellulose activities”, Pure appl.chem., Vol. 59: 257-268, 1987.

[8] S. Nagendran, H.E. Hallen-Adams, J.M. Paper, N. Aslam, and J.D. Walton, "Reduced genomic potential for secreted plant cell-wall-degrading enzymes in the ectomycorrhizal fungus Amanita bisporigera, based on the secretome of Trichoderma reesei", Fungal Genetics and Biology, Vol. 46(5), 427-435, 2009. doi: 10.1016/j.fgb.2009.02.001

[9] G.L. Miller, "Use of dinitrosalicylic acid reagent for determination of reducing sugar", Analytical chemistry, Vol. 31(3), 426-428, 1959. D0I: $10.1021 /$ ac60147a030

[10] K.I. Jo, Y.J. Lee, B.K. Kim, B.H. Lee, C.H. Chung, S.W. Nam, and J.W. Lee, "Pilot-scale production of carboxymethylcellulase from rice hull by Bacillus amyloliquefaciens DL-3”, Biotechnology and Bioprocess Engineering, Vol. 13(2), 182, 2008. doi:10.1007/s12257-007-0149-y

[11] L. Mayende, B.S. Wilhelmi, and B.I. Pletschke, “Cellulases (CMCases) and polyphenol oxidases from thermophilic Bacillus spp. isolated from compost, Soil Biology and Biochemistry, Vol. 38(9), 2963-2966, 2006. doi:10.1016/j.soilbio.2006.03.019

[12] B.K. Kim, B.H. Lee, Y.J. Lee, I.H. Jin, C.H. Chung, and J.W. Lee, "Purification and characterization of carboxymethylcellulase isolated from a marine bacterium, Bacillus subtilis subsp. subtilis A-53", Enzyme and Microbial Technology, Vol. 44(6-7), 411-416, 2009. doi:10.1016/j.enzmictec.2009.02.005

[13] S. Shanmughapriya, G.S. Kiran, J. Selvin, T.A. Thomas, and C. Rani, “Optimization, purification, and characterization of extracellular mesophilic alkaline cellulase from sponge-associated Marinobacter sp. MSI032”, Applied biochemistry and biotechnology, 162(3), 625-640, 2010. doi:10.1007/s12010-0098747-0

[14] K. Kathiresan, and S. Manivannan, " $\alpha$-Amylase production by Penicillium fellutanum isolated from mangrove rhizosphere soil", African journal of Biotechnology, 5(10), 2006.

[15] J. Singh, N. Batra, and R.C. Sobti, "Purification and characterisation of alkaline cellulase produced by a novel isolate, Bacillus sphaericus JS1", Journal of Industrial Microbiology and Biotechnology, Vol. 31(2), 51-56, 2004. doi:10.1007/s10295-004-0114-0

[16] J.Y. Kim, S.H. Hur, and J.H. Hong, "Purification and characterization of an alkaline cellulase from a newly isolated alkalophilic Bacillus sp. HSH-810", Biotechnology letters, Vol. 27(5), 313-316, 2005. doi:10.1007/s10529-005-0685-5

[17] M. Irfan, Q. Mushtaq, F. Tabssum, H.A. Shakir, and J.I. Qazi, “Carboxymethyl cellulase production optimization from newly isolated thermophilic Bacillus subtilis K-18 for saccharification using response surface methodology”, AMB Express, Vol. 7(1), 29, 2017. https://doi.org/10.1186/s13568-017-0331-3

[18] Y.H. Li, M. Ding, J. Wang, G.J. Xu, and F. Zhao, "A novel thermoacidophilic endoglucanase, Ba-EGA, from a new cellulose-degrading bacterium, Bacillus sp. AC-1", Applied Microbiology and Biotechnology, Vol. 70(4), 430-436, 2006. doi:10.1007/s00253-005-0075-x

[19] C. Mawadza, R. Hatti-Kaul, R. Zvauya, and B. Mattiasson, "Purification and characterization of cellulases produced by two Bacillus strains", Journal of biotechnology, Vol. 83(3), 177-187, 2000. doi:10.1016/s0168-1656(00)00305-9

[20] Y.J. Lee, B.K. Kim, B.H. Lee, K.I. Jo, N.K. Lee, C.H. Chung, and J.W. Lee, "Purification and characterization of cellulase produced by Bacillus amyoliquefaciens DL-3 utilizing rice hull”, Bioresource technology, Vol. 99(2), 378-386, 2008. doi:10.1016/j.biortech.2006.12.013

[21] C. Ganesh Kumar, and H. Takagi, “Microbial alkaline proteases: From a bioindustrial viewpoint”, Biotechnology advances, Vol. 17(7), 561-594, 1999.

[22] K.A. Abou-Taleb, W.A. Mashhoor, S.A. Nasr, M.S. Sharaf, and H.H. Abdel-Azeem, "Nutritional and environmental factors affecting cellulase production by two strains of cellulolytic Bacilli", Australian Journal of Basic and Applied Sciences, Vol. 3(3), 2429-2436, 2009.

[23] A.K. Ray, A. Bairagi, K.S. Ghosh, and S.K. Sen, "Optimization of fermentation conditions for cellulase production by Bacillus subtilis CY5 and Bacillus circulans TP3 isolated from fish gut”, Acta Ichthyologica et Piscatoria, Vol. 1(37), 47-53, 2007. D0I: 10.3750/AIP2007.37.1.07

[24] H. Ariffin, N. Abdullah, U.K. Md Shah, Y. Shirai, and M.A. Hassan, "Production and characterization of cellulases by Bacillus pumilus EB3”, International Journal of Engineering and Technology, Vol. 3(1), 47-53, 2006.

[25] L.L. Lin, C.C. Chyau, and W.H. Hsu, "Production and properties of a raw-starch-degrading amylase from the thermophilic and alkaliphilic Bacillus sp. TS-23", Biotechnology and applied biochemistry, Vol. 28(1), 61-68, 1998.

[26] A. Aygan, B. Arikan, H. Korkmaz, S. Dincer, and O. Colak, "Highly thermostable and alkaline cellulase from Halotolerant-alkaliphilic Bacillus sp. AB 68", Braz .J. Microbiol., Vol. 39:547-553, 2008. 